\title{
Colloidal Metal Surfaces as Biosensors of Biological Samples
}

\author{
Agnieszka Tąta ${ }^{a}$, Barbara Gralec ${ }^{\mathrm{b}}$, Edyta Proniewicz ${ }^{\mathrm{a}, *}$ \\ ${ }^{a}$ AGH University of Science and Technology, Faculty of Foundry Engineering, Reymonta 23, 30-059 Krakow, Poland \\ ${ }^{\mathrm{b}}$ University of Warsaw, Faculty of Chemistry, Pasteura 1, 02-093 Warsaw, Poland \\ *e-mail: proniewi@agh.edu.pl
}

Received: 17 November 2016/Accepted: 20 January 2017/Published online: 17 March 2017

This article is published with open access at AGH University of Science and Technology Press

\begin{abstract}
Colloidal solutions of silver (AgNPs), gold (AuNPs), and platinum nanoparticles (PtNps) obtained under controlled conditions in an aqueous media by chemical methods were used as effective biosensors of biological compounds such as bombesins (BN). The BN adsorption at the metal/aqueous interface was investigated by surface-enhanced Raman scattering (SERS). Briefly, the spectral pattern of BN in the silver, gold, and platinum sols is strongly influenced by the indole ring vibrations of L-tryptophan at position 8 of the amino acid sequence ( $\left.\operatorname{Trp}^{8}\right)$. In addition, L-methionine (Met) at the C-terminus determines the BN adsorption, mainly onto the AuNPs and AgNPs surfaces.
\end{abstract}

\section{Keywords:}

colloidal gold nanoparticles, AuNPs; colloidal silver nanoparticles, AgNPs; colloidal platinum nanoparticles, PtNPs; surface-enhanced Raman Scattering, SERS; bombesin, BN

\section{INTRODUCTION}

Nanoparticles are particles of microscopic size, having size below $100 \mathrm{~nm}$ in at least one dimension. They show a substantially greater the surface-area to volume ratio, what makes them better candidates than their bulk counterparts in the terms of their activity [1-2]. Recently, metal nanoparticles, due to their properties, are widely used as antistatic materials, biosensors, conductive inks, adhesives for different electronics, and in switching devices [3-6].

Surface-enhanced Raman scattering (SERS) is a powerful tool for the characterization of molecule adsorption at a metal/liquid interface [7]. This technique has excellent frequency resolution and unique structural sensitivity at low molecule concentration due to amplification of the electromagnetic field generated by the localized surface plasmon excitation [8]. This provides information about these molecular fragments, which are in the metal vicinity or binding to the metal surface. Thus, it allows us to describe the mode of interaction between the investigated compound and metal surface [9]. The most-common metals used in SERS are those belonging to coinage metals (i.e., silver and gold) because their plasmon bands are in the visible and infrared wavelength regions. Although platinum has recently been applied as an alternative plasmonic material, its plasmon band is in the UV region [10]. These metals are most-often used in the form of colloids [11], surfaces obtained in the repetitive electrochemical oxidation-reduction cycles (ORC) [12], vapor-deposited metal island films [13], and lithographyproduced nanostructures [14].

In this work, bombesin (BN) was immobilized onto the aqueous solution/colloidal platinum (PtNPs, diameter of $10 \mathrm{~nm}$ ), gold (AuNPs, diameter of $20 \mathrm{~nm}$ ), and silver (AgNPs, diameter of $40 \mathrm{~nm}$ ) nanoparticle interfaces $[15,16]$, and the subsequent adsorption was investigated by SERS. Bombesin (pGlu-Gln-Arg-Leu-GlyAsn-Gln-Trp-Ala-Val-Gly-His-Leu-Met- $\mathrm{NH}_{2}$, where pGlu denotes to 5-oxo-proline) is an endogenous neurotransmitter found in humans as well as many other mammals. In humans, BN binds with a high affinity to bombesin receptor subtype 3 (BRS-3 and $\mathrm{BB}_{3}$ receptor), a member of the G protein-coupled receptor superfamily [17-19]. These receptors activate a complex network of signalling pathways and biological responses, including hyperglycemia, hypertension, hyperinsulinemia, contraction of uterus, colon, or ileum, locomotor activity, and stimulation of gastric secretion. Also, it stimulates the growth of various tumor cell lines; for example, lung, prostate, stomach, pancreas, colon, and breast cancers. Such a large variety of BN biological functions has caused interest in understanding its adsorption at solid/liquid interfaces and the relationship between the BN function and structure [20-24].

\section{EXPERIMENTAL PART}

\subsection{Materials}

A bombesin (BN) was purchased from Bachem Co., Switzerland, and used without further purification. A gold colloid solution (AuNPs, $\sim 20 \mathrm{~nm}$ size, concentration: $\sim 0.01 \%$ as $\mathrm{HAuCl}_{4}$ ) was purchased from Sigma (Poland). A silver colloid solution (AgNPs, $\sim 40 \mathrm{~nm}$ size) was purchased from Sigma (Poland). 


\subsection{Synthesis of platinum colloid}

A solution of colloidal platinum nanoparticles was obtained by the reduction of platinum(II) chloride by ethylene glycol. Ethylene glycol also served as the reaction medium. The platinum nanoparticles (PtNPs) obtained with this method were separated from the reaction medium by repeated centrifugation and washing with distilled water [25].

\subsection{RS measurement}

FT-Raman measurements were performed for a sample placed on a glass plate. The FT-Raman spectra were recorded on a Nicolet spectrometer (model NXR 9650) equipped in a liquid-nitrogen-cooled germanium detector. Typically, 1000 scans were collected, each with a resolution of $4 \mathrm{~cm}^{-1}$. Excitation at $1064 \mathrm{~nm}$ was used from a continuum-wave $\mathrm{Nd}^{3+}$ :YAG laser in a spectral range of $3650-450 \mathrm{~cm}^{-1}$. The output laser power was maintained at $200 \mathrm{~mW}$.

\subsection{SERS measurements}

The SERS spectra were collected using each of the platinum, silver, and gold sols from three different bottles. From each bottle, three sol samples of $40 \mu \mathrm{l}$ were taken out and mixed with $20 \mu \mathrm{l}$ of bombesin solution $\left(10^{-4} \mathrm{Mol} / \mathrm{dm}^{3}\right)$. The final peptide concentration was $3 \cdot 10^{-5} \mathrm{Mol} / \mathrm{dm}^{3}$. The mixture was incubated for $180 \mathrm{~min}$; then, the $20 \mu \mathrm{l}$ peptide/gold sol mixture was placed on the glass plate, and the SERS spectra were collected.

The SERS spectra were collected using an InVia Raman microspectrometer (Renishaw) equipped with an aircooled charge-coupled device (CCD) detector and a Leica microscope $(50 \times$ long-distance objective). The spectral resolution was set at $4 \mathrm{~cm}^{-1}$. The $785 \mathrm{~nm}$ line of a diode laser was used as the excitation source. Laser power at the output was set at $40 \mathrm{~mW}$. The typical exposure time for each SERS measurement was $40 \mathrm{~s}$ with six accumulations (a series of six spectra, each accumulated $40 \mathrm{~s}=240 \mathrm{~s}$ ). The obtained spectra were almost identical except for small differences in some band intensities (up to $4 \%$ ). No spectral changes that could be associated with the sample decomposition were observed during these measurements.

\section{RESULTS AND DISCUSSION}

Figure 1 presents the FT-Raman spectrum (A) and SERS spectra of the bomesin deposited onto the surface of the colloidal nanoparticles of platinum (B), gold (C), and silver (D). Table 1 summarizes the wavenumbers and band allocations for the normal mode motions of the bands observed in these spectra. The bands assignment is based on our previous studies on the BN adsorption onto the surfaces of silver [15] and gold [16].

The SERS spectrum of $\mathrm{BN}$ in the platinum sol (Fig. 1B) shows bands mainly due to the vibrations of the indole ring of the $\operatorname{Trp}^{8}$ residue. These include bands at 1617 [phenyl+pyrrole and $v\left(\mathrm{~N}_{1}-\mathrm{H}\right)$ ], 1555 [pyrrole $v\left(\mathrm{C}_{2}=\mathrm{C}_{3}\right)$ ], 1443 [pyrrole $v_{\mathrm{s}}\left(\mathrm{N}_{1} \mathrm{C}_{2} \mathrm{C}_{3}\right)+\delta\left(\mathrm{N}_{1}-\mathrm{H}\right)$ and phenyl $\delta(\mathrm{CH})$ ], 1360 [indole $v\left(\mathrm{~N}_{1}-\mathrm{C}_{8}\right)$ ], 1013 [out-of-phase phenyl ring breathing], $879\left[\delta\left(\mathrm{N}_{1}-\mathrm{H}\right)\right.$ and Fermi resonance between ring breathing and o.o.p. ring bending], and $760 \mathrm{~cm}^{-1}$ [sym. pyrrole ring breathing]. These bands show similar intensity as the Raman intensity; however, they are significantly broadened as compared with those in the BN FT-Raman spectrum (Fig. 1A) (i.e., $\Delta_{\text {fwhm1555 }}=10 \mathrm{~cm}^{-1}, \Delta_{\mathrm{fwhm} 1013}=12 \mathrm{~cm}^{-1}$, and $\Delta_{\mathrm{fwhm} 760}=8 \mathrm{~cm}^{-1}$; fwhm - full-width at half maximum). Thus, it can be stated that the indole ring adopts a rather perpendicular orientation in respect to the PtNPs surface [26]. In addition, the weak $\mathrm{C}-\mathrm{S}$ stretching vibrations at $715\left(\mathrm{P}_{\mathrm{C}}\right.$-T conformer) and $700 \mathrm{~cm}^{-1}\left(\mathrm{P}_{\mathrm{C}^{-}} \mathrm{G}\right.$ conformer) and the amide I band $\left(\alpha\right.$-helix) at $1671 \mathrm{~cm}^{-1}[27,28]$ suggest that the Met's sidechain, being in two conformations, and amide bond participate in BN adsorption onto the PtNPs surface.

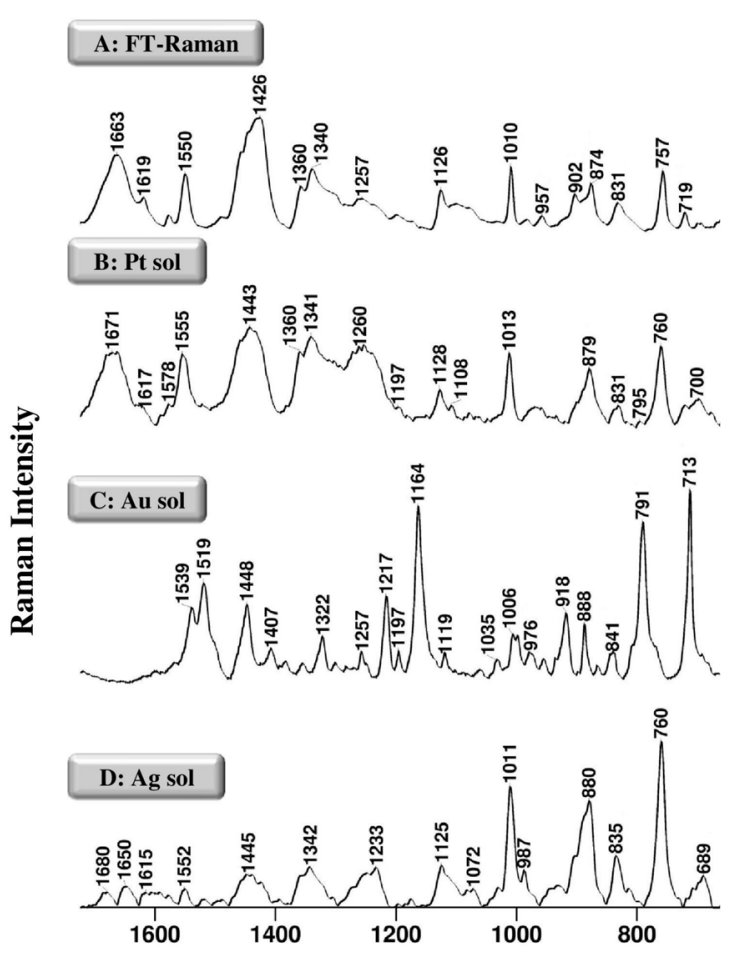

Fig. 1. The FT-Raman spectrum of BN (A) and SERS spectra of BN adsorbed onto PtNPs (B), AuNPs (C), and AgNPs (D) surfaces in a spectral range of $1800-450 \mathrm{~cm}^{-1}$

The SERS spectrum of BN immobilized onto the AuNPs surface (Fig. 1C) is also dominated by the $\operatorname{Trp}^{8}$ bands; i.e., at 1539 [W3], 1448 [W6], 1257 [W10], 1217 $\left[\rho_{\mathrm{t}}\left(\mathrm{CH}_{2}\right)_{\mathrm{Tr}}\right], 1164$ [W12], 1006 [W16], 888 [W17], and 791 [W18] (see Table 1 for detailed band assignments). Based on the intensity of the W3 $\left[v\left(\mathrm{C}_{2}=\mathrm{C}_{3}\right)\right], \mathrm{W} 12$ [ $\delta$ (pyrrole and benzene ring)], W18 [symmetric phenyl/ pyrrole ring breathing], and $\rho_{\mathrm{t}}\left(\mathrm{CH}_{2}\right) \operatorname{Trp}$ modes, it can be stated that the indole ring is directed towards gold 
through the $\mathrm{C}_{2}=\mathrm{C}_{3}$ moiety in a way that allows the $-\mathrm{CH}_{2}$ - of $\mathrm{Trp}^{8}$ group to approach the AuNPs surface. Likewise, the $-\mathrm{S}-\mathrm{CH}_{3}$ Met's side-chain is directed towards AuNPs. This is manifested by the appearance of a very strong $713 \mathrm{~cm}^{-1}$ spectral feature $\left(\Delta_{\text {fwhm }}=25 \mathrm{~cm}^{-1}\right)$. Therefore, it seems that the Met's side-chain, being in the PC-T conformation, binds to AuNPs [27, 28]. Also, the amide bond and imidazole ring of $\mathrm{His}^{12}$ strongly interact with the AuNPs surface. This statement is based on observation of the $1519 \mathrm{~cm}^{-1}$ SERS signal due to the amide II mode and the $918 \mathrm{~cm}^{-1}$ spectral feature due to the $\mathrm{His}^{12}$ oscillations $\left[\delta(\right.$ ring $\left.)+\delta\left(\mathrm{N}_{1}-\mathrm{H}\right)\right]$.

In the AgNPs sol (Fig. 1D), BN also binds to the metal through the L-tryptophan residue; thus, the 1615 [W1], 1552 [W3], 1445 [W6], 1011 [W16], 880 [W17], and
760 [W18] SERS signals are observed in its SERS spectrum. From these, the most interesting bands are those at $1011\left(\Delta_{\text {fwhm }}=28 \mathrm{~cm}^{-1}\right)$ and $760 \mathrm{~cm}^{-1}\left(\Delta_{\text {fwhm }}=32 \mathrm{~cm}^{-1}\right)$. Based on these band intensities and widths, it can be suggested that the indole ring (phenyl and pyrrole rings) of Trp adopts an edge-on orientation in respect to the AgNPs surface, wherein the pyrrole co-ring is located closer to the AgNPs surface. In this orientation, the $\mathrm{N}_{1}-\mathrm{H}$ bond of the pyrrole co-ring is strongly coordinated to this surface. On the other hand, the weak 1680 (random coil) and $1650 \mathrm{~cm}^{-1}$ ( $\alpha$-helix) spectral features due to the amide bond vibrations as well as the very strong $689 \mathrm{~cm}^{-1}$ band ( $\mathrm{P}_{\mathrm{C}}-\mathrm{G}$ conformer) due to the $\mathrm{C}-\mathrm{S}$ bond vibrations pointed out that these molecular fragments participate in the interaction with AgNPs.

Table 1

Wavenumbers and proposed bands assignment for FT-Raman spectrum and SERS spectra of BN adsorbed onto the colloid platinum, gold, silver surface

\begin{tabular}{|c|c|c|c|c|}
\hline \multirow{2}{*}{ Assignment } & \multicolumn{4}{|c|}{ Wavenumber, $\mathbf{c m}^{-1}$} \\
\hline & FT-Raman & PtNPs & AuNPs & AgNPs \\
\hline Amide I (Random coil) & - & - & - & 1680 \\
\hline Amide I ( $\alpha$-helisa) & 1663 & 1671 & - & 1650 \\
\hline W1[phenyl + pyrrole $\left.v\left(\mathrm{~N}_{1}-\mathrm{H}\right)\right]$ & 1619 & 1622 & - & 1615 \\
\hline W2 [phenyl] & - & 1578 & - & - \\
\hline W3 [pyrrole $\left.v\left(\mathrm{C}_{2}=\mathrm{C}_{3}\right)\right]$ & 1550 & 1555 & 1539 & 1552 \\
\hline Amide II & - & - & 1519 & - \\
\hline W6 [pyrrole $v_{s}\left(\mathrm{~N}_{1} \mathrm{C}_{2} \mathrm{C}_{3}\right)+\delta\left(\mathrm{N}_{1}-\mathrm{H}\right)$ and phenyl $\left.\delta(\mathrm{CH})\right]$ & - & 1443 & 1448 & 1445 \\
\hline His $\left[\delta\left(\mathrm{C}_{2}-\mathrm{H}\right)+\delta(\mathrm{N} 1-\mathrm{H})\right]$ & 1426 & - & 1407 & - \\
\hline W7 [pyrrole ring $v\left(\mathrm{~N}_{1}-\mathrm{C}_{8}\right)$ ] & 1360 & 1360 & - & - \\
\hline$v\left(\mathrm{C}-\mathrm{NH}_{2}\right)$ & 1340 & 1341 & 1322 & 1342 \\
\hline $\operatorname{His}\left[\delta(\right.$ ring $\left.)+\rho_{\text {ipb }}\left(\mathrm{C}_{2}-\mathrm{H}\right)\right]$ & - & - & - & - \\
\hline Amide III & 1257 & 1260 & - & - \\
\hline $\mathrm{W} 10\left[v\left(\mathrm{C}_{3}-\mathrm{C}_{\beta}\right)+v(\mathrm{C}-\mathrm{H})\right]$ & - & - & 1257 & - \\
\hline$\rho \tau\left(\mathrm{CH}_{2}\right)_{\text {Trp }}$ & - & 1217 & 1217 & 1233 \\
\hline$v\left(\mathrm{C}-\mathrm{N}_{\mathrm{A}}\right), \rho_{\mathrm{b}}\left(\mathrm{C}_{\mathrm{A}} \mathrm{N}_{\mathrm{A}} \mathrm{HC}\right), \delta\left(\mathrm{CC}_{\mathrm{A}} \mathrm{O}_{\mathrm{A}} \mathrm{NA}\right)$ & - & 1197 & 1197 & - \\
\hline $\mathrm{W} 12\left[\delta\left(\mathrm{N}_{1}-\mathrm{H}\right)\right]$ & - & - & 1164 & - \\
\hline$v_{\text {as }}(\mathrm{CCN}), \delta\left(\mathrm{C}-\mathrm{NH}_{2}\right), \delta\left(\mathrm{NCH}_{2} \mathrm{C}_{\mathrm{A}}\right), v\left(\mathrm{C}-\mathrm{N}_{\mathrm{A}}\right)$ & 1126 & 1128 & 1119 & 1125 \\
\hline His $\left[\boldsymbol{\rho}_{\mathrm{ipb}}\left(\mathrm{C}_{2}-\mathrm{H}\right)\right], \rho_{\tau}\left(\mathrm{NH}_{2}\right)$ & - & 1108 & - & 1072 \\
\hline$v(\mathrm{C}-\mathrm{C})$ & - & - & 1035 & - \\
\hline W16 [phenyl and pyrrole ring out-of-phase breathing] & 1010 & 1013 & 1006 & 1011 \\
\hline His [ $\delta$ (ring)], $v(\mathrm{CN}), \rho_{\mathrm{b}}\left(\mathrm{NH}_{2}\right)$ & - & - & - & 987 \\
\hline$v(\mathrm{C}-\mathrm{C} / \mathrm{N}) \delta\left(\mathrm{C}-\mathrm{NH}_{2}\right)$ & 957 & - & - & - \\
\hline$\left[\delta(\right.$ ring $\left.)+\delta\left(\mathrm{N}_{1}-\mathrm{H}\right)\right]$ & 902 & - & 918 & - \\
\hline W17 [ $\delta\left(\mathrm{N}_{1}-\mathrm{H}\right)$ and Fermi resonance between ring breathing and o.o.p. ring bending] & 874 & 879 & 888 & 880 \\
\hline$v_{\text {as }}(\mathrm{CSC})$ or W11 [phenyl] & 831 & 831 & 841 & 835 \\
\hline W18 [sym phenyl/pyrrole ring breathing] & 757 & 762 & 791 & 760 \\
\hline$v(\mathrm{C}-\mathrm{S}) \mathrm{P}_{\mathrm{C}} \mathrm{T}$ or $\mathrm{W} 19$ & 719 & 715 & 713 & - \\
\hline$v(\mathrm{C}-\mathrm{S}) \mathrm{P}_{\mathrm{C}^{-}} \mathrm{G}$ & 685 & 700 & - & 689 \\
\hline
\end{tabular}

Abbreviations: $v$ - stretching; $v_{\text {as }}$ - antisymmetric stretching, $v_{\mathrm{s}}$ - symmetric stretching; $\delta$ - deformation; $\rho_{\text {oop }}$ - out-of-plane deformation; $\rho_{\mathrm{ipb}}$ - in- plane deformation; $\delta$ - symmetric deformation; $\rho_{\omega}$ - wagging; $\rho_{\mathrm{b}}$ - bending; $\rho_{\mathrm{r}}$ - rocking; and $\rho_{\mathrm{\tau}}$ - twisting vibrations; $\mathrm{W}$ - tryptphan modes; $\mathrm{C}_{\mathrm{A}}$ - the carbon atom of the amide bond; $\mathrm{N}_{\mathrm{A}}$ - the nitrogen atom of the amide bond; $\mathrm{O}_{\mathrm{A}}$ - the oxygen atom of the amide bond 


\section{CONCLUSION}

Colloidal solutions of silver, gold, and platinum nanoparticles obtained in controlled condition in an aqueous media by chemical methods were successfully used as effective biosensors of biological compounds such as bombesins (BN). The adsorption of BN at a metal/aqueous interface was investigated by surface-enhanced Raman scattering (SERS).

Based on the analysis of the SERS spectra, the following conclusions can be drawn:

- the $\operatorname{Trp}^{8}$ residue is responsible for the peptide interaction with metal at the PtNP/aqueous, AuNPs/aqueous, and AgNPs/aqueous intefaces. However, the geometry of the indole ring with respect to the metal surface depends on the metal type;

- change of the metal surface causes changes in the manner and strength of binding of the peptide C-terminus to metal;

- there is no evidence suggesting that the peptide N-terminus interacts with any studied biosensor.

\section{Acknowledgements}

This work was supported by the postdoctoral project of AGH University of Science and Technology, Faculty of Foundry Engineering (Grant No. 15.11.170.572). The authors gratefully acknowledge Adam Lewera, the University of Warsaw, Faculty of Chemistry, Warsaw, Poland, for donating the platinum nanoparticles.

\section{REFERENCES}

[1] Annamalai A., Sarah T.B., Niji A.J., Sudha D. \& Christina P. (2011). Biosynthesis and characterization of silver and gold nanoparticles using aqueous leaf extraction of Phyllanthus amarus Schum \& Thonn. World Applied Sciences Journal, 8(13), 1833-1840.

[2] Raimondi F., Scherer G.G. \& Kotz R. (2005). Nanoparticles in energy technology: examples from electrochemisy and catalysis. Chemie International Edition, 44(56), 2190-2209.

[3] Rubilar 0. (2013). Biogenic nanoparticles: Copper, copper oxides, copper sulphides, complex copper nanostructures and their applications. Biotechnology Letters, 35(54), 1365-1375.

[4] Bouvree A., Feller J.F., Castro M., Grohen Y. \& Rinaudo M. (2009). Conductive polymer nano-biocomposites (CPC): chitosan-carbon nanoparticle a good candidate to design polar vapour sensors. Sensors and Actuators B: Chemical, 138(6), 138-147.

[5] Park S. \& Kim H. (2014). Flash light sintering of nickel nanoparticles for printed electronics. Thin Solid Films, 500, 575-581.

[6] Shen W., Zhang X., Huang Q., Xu Q. \& Song W. (2014). Preparation of solid silver nanoparticles for inkjet printed flexible electronics with high conductivity. Nanoscale, 6(8), 1622-1628.

[7] Akbarian F., Dunn B.S \& Zink J.I. (1995). Surface-enhanced Raman Spectroscopy using photodeposited gold particles in porous sol-gel silicates. Journal of Physical Chemistry, 98(6), 3892-3894.

[8] Liu Z., Yang Z.L., Cui L., Ren B. \& Tian Z.Q. (2007). Electrochemically roughened palladium electrodes for surface-enhanced Raman spectroscopy: methodology, mechanism and application. Journal of Physical Chemistry C, 111(15), 1770-1775.

[9] Podstawka-Proniewicz E., Sobolewski D., Prahl A., Kim Y., Proniewicz L.M. (2012). Structure and conformation of $\mathrm{Arg}^{8}$ vasopressin modified analogs. Journal of Raman Spectroscopy, 43(16), 51-60.
[10] Volkan M., Stokes D.L. \& Vo-Dinh T. (1999). A new surfaceenhanced Raman scattering substrate based on silver nanoparticles in sol-gel. Journal of Raman Spectroscopy, 30(20), 1057-1065.

[11] Fleischmann M., Hendra P.J. \& McQuillan A.J. (1974). Raman spectra of pyridine adsorbed at a silver electrode. Chemical Physics Letters, 26(10), 163-166.

[12] Zeisel D., Deckert V., Zenobi R. \& Vo-Dinh T. (1998). Near-field surface-enhanced Raman spectroscopy of dye molecules adsorbed on silver island film. Chemical Physics Letters, 283(43), 381-385.

[13] Dick L.A., McFarland A.D., Haynes C.L. \& Van Duyne R.P. (2002). Metal film over nanosphere (MFON) electrodes for surfaceenhanced Raman spectroscopy (SERS): improvements in surface nanostructure stability and suppression of irreversible loss. Journal of Physical Chemistry B, 106(16), 853-860.

[14] Podstawka E., Ozaki Y. \& Proniewicz L.M. (2005). Part III: Surface-enhanced Raman scattering of amino acids and their homoipeptide monolayers deposited onto colloidal gold surface. Applied Spectroscopy, 59(12), 1516-1526.

[15] Podstawka-Proniewicz E., Ozaki Y., Kim Y., Xu, Y. \& Proniewicz L.M. (2011). Surface-enhanced Raman scattering studies on bombesin, its selected fragments and related peptides adsorbed at the silver colloidal surfac. Applied Surface Science, 89, 8246-8252.

[16] Tąta A., Szkudlarek A., Kim Y. \& Proniewicz E. (2016). Adsorption of bombesin and its carboxyl terminal fragments onto the colloidal gold nanoparticles: SERS studies. Vibrational Spectroscopy, 84, 1-6.

[17] Tsuboi M., Overman S.A., Nakamura K., Rodriguez-Casado A. \& Thomas G.J.Jr. (1996). Orientation and interactions of an essential tryptophan (Trp-38) in the capsid subunit of Pf3 filamentous virus. Journal of Molecular Structure, 379, 43-50.

[18] Rivier J.E. \& Brown M.R. (1978). The effects of the phyllolitorin analogue [desTrp ${ }^{3}$, Leu ${ }^{8}$ ]phyllolitorin on scratching induced by bombesin and related peptides in rats. Biochemistry, 17, 1766-1771.

[19] Zachary E. \& Rozengurt A. (1993). Handbook of experimental pharmacology "dendritic cells": the use of dexamethasone in the induction of tolerogenic DCs. Handbook of Experimental Pharmacology, 106, 343-350.

[20] Gore M.E., Preston N., A'Hern R.P., Hill C., Mitchell P., Chang J. \& Nicolson M. (1995). Platinum-Taxol non-cross resistance in epithelial ovarian cancer. British Journal of Cancer, 71(6), 1087-1098.

[21] Hoki-Hamzaki H., Iwabuchi M. \& Makewa F. (2005). Development and function of bombesin-like peptides and their receptors. Journal of Developmental Biology, 49(4), 293-300.

[22] Moody T.M., Fagarasan M. \& Zia F. (1995). A GRP receptor antagonist which inhibits small-cell lung-cancer growth. Life Sciences, 56(7), 521-529.

[23] Battey J.F. \& Wada E. (1991). Two distinct receptor subtypes for mammalian bombesin-like peptides. Trends in Neurosciences, 14(12), 524-534.

[24] Markwalder R. \& Reubi J.C. (1999). Gastrin-releasing peptide receptors in non-neoplastic and neoplastic human breast. Cancer Research, 59(6), 1152-1159.

[25] Januszewska A., Dercz G., Piwowar J., Jurczakowski R. \& Le-wera A. (2013). Outstanding catalytic activity of ultrapure platinum nanoparticles. Chemistry: A European Journal, 19(50), 17159-17164.

[26] Shriver S.P. (2000). Sex-specific expression of gastrin-releasing peptide receptor: relationship to smoking history and risk of lung cancer. Journal of the National Cancer Institute, 92(1), 24-33.

[27] Mizushima S., Shimanouchi T., Nakamura K., Hayashi M. \& Tsuchiya S. (1957). C-Cl stretching frequencies in relation to rotational isomerism. Journal of Chemical Physics, 26, 970-975.

[28] Nogami N., Sugeta H. \& Miyazaw T. (1975). Vibrational Spectra and Molecular Structure of Ethyl Methyl Sulfide. Bulletin of the Chemical Society of Japan, 48(12), 2417-2425. 